\title{
Data integrity aspects of reporting results for the specification parameter related and degradation products in chromatography data system
}

\author{
Milena Dobrkovikj Shotarovska $^{1 *}$, Hristina Babunovska $^{1}$, Aneta Dimitrovska $^{2}$

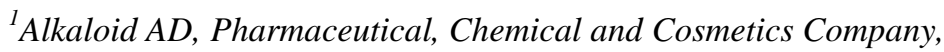 \\ Aleksandar Makedonski 12, 1000 Skopje, Republic of Macedonia \\ ${ }^{2}$ Ss. Cyril and Methodius ${ }^{2}$ University, Faculty of Pharmacy, Majka Tereza 47, 1000 Skopje, \\ Republic of Macedonia
}

Received: September 2018; Accepted: October 2018

\begin{abstract}
The most convenient way to implement the requirements of Good Manufacturing Practice and the data integrity principles in a control analytical laboratory is to automate the entire analytical process as fully as possible. Obtaining a final reliable result from an analytical testing as part of a formal analysis is one segment of the process of providing Good Manufacturing Practice. In this paper, we describe the steps by which one control analytical laboratory can formalize and automate the entire process of obtaining and issuing analytical results through creating Report Template for calculation of the specification parameter Related and Degradation Products as part of a Chromatography Data System. The process is described in several steps from designing and structuring of the report so that it would respond best to the end-user's requirements, through identifying eventual oversights in the creation phase, to the final phase of validation, which once again confirms the integrity of its content and justifies its use for formal analysis.

The use of such validated Report Templates for calculation and reporting of the results from analytical testing eliminates the human error factor and increases the confidence in the issued results as well as in the entire laboratory's workflow. Their application facilitate compliance with regulations and minimizes manual input of data which in turn meets one of the most crucial requirements of Good Manufacturing Practice.
\end{abstract}

Keywords: data integrity, chromatography data system, report template, related and degradation products

\section{Background}

Fulfillment and application of the strict requirements from regulatory agencies in the production and analysis of pharmaceutical products is a major challenge for the pharmaceutical industry. A critical point in meeting these requirements is establishing a robust system that provides data integrity. Data integrity is not a new concept in the pharmaceutical industry and has always been a fundamental segment for providing Good Manufacturing Practice; however, it has been actualized in the last few years with numerous guidelines issued by key regulatory bodies from Europe and the USA. The reason for the increased interest results from the increased awareness of regulatory agencies for the failure of organizations/pharmaceutical industries to establish such robust system for protection of data, as well as possible timely detection of reasons that led to compromising this data (WHO, 2016).

\footnotetext{
*mdobrkovic@alkaloid.com.mk
} 
The concept of data integrity denotes the degree to which the data collection process is complete, consistent and accurate over the entire lifecycle. The lifecycle of a data includes all stages it passes through, from its initial creation to processing, usage, storage and retrieval and possible destruction. Data integrity should provide recoverability, search ability, and traceability of any original record, regardless of the process, format, or technology used in its generation, storage, processing or recovery. Data refers to all original records and true copies of original records, including source data and metadata as well as any additional transformations and reports of these data, generated and saved at the moment of activity with the possibility for full and complete reconstruction and evaluation of that activity (Churchward, 2015a; GAMP, 2017; MHRA, 2018).

Data integrity is based on the ALCOA+ principle Who? What? How? Why?

The acronym ALCOA refers to Attributable, Legible, Contemporaneous, Original and Accurate and the '+' refers to Complete, Consistent, Enduring and Available (Churchward, 2015b; GAMP, 2017; MHRA, 2015).

In other words, when generating data:

- Data must be attributable to the individual producing the data, that is, who performed the activity, on which instrument and at what time (Churchward, 2015b; GAMP, 2017; MHRA, 2015).

- Data must be legible and enduring throughout their entire lifecycle, that is, it should not be possible to modify or re-create data without traceability that is stored in the original record (Churchward, 2015b; GAMP, 2017; MHRA, 2015).

- Data must be contemporaneous, recorded at the moment when is created (Churchward, 2015b; GAMP, 2017; MHRA, 2015).

- Data must be in their original form (printed or electronic) or a true copy, identical certified copy of the original record (Churchward, 2015b; GAMP, 2017; MHRA, 2015).

- Data must be accurate, in other words, no changes or corrections can be made without having a documented record of this change (Churchward, 2015b; GAMP, 2017; MHRA, 2015).

Data management is the key in all activities related to ensuring data integrity.

These activities, in addition to the above mentioned, should ensure that the data is complete, consistent, enduring throughout their entire lifecycle and readily available for review or inspection (21 CFR, Chapter 1, Part 221.180). Providing data integrity is not only a requirement of the regulatory bodies for Good Manufacturing Practice but also an imperative for proper functioning and fulfillment of the basic goal of the pharmaceutical industry, the production of medicines with the required quality, safety and efficiency.

\section{Chromatography Data System}

The principles of data integrity should be implemented in all spheres of the pharmaceutical industry, including the overall workflow in a control analytical laboratory. Chromatography is the leading analytical technique in a control analytical laboratory and it accounts for up to $80 \%$ of the total number of performed analyses. Hence emerged the need to develop Chromatography Data System for control and automation of chromatographic analyses - starting from control of instruments from different manufacturers, to running analyses, data processing and reporting of the results. The purpose of implementing such a system in a control analytical laboratory is to automate the entire process, eliminate paper data and replace them with electronic data. The electronic form of generating and storing data is much more complete and maintains traceability much more successfully than what is achieved with printed chromatograms which are static data. The review of electronic data provides more relevant and comprehensive information and all activities related to these data can be reconstructed - who did what, when and why. With the installation and implementation of such integrated system that generates, manages and stores electronic data, falsification of data is deterred and more easily detected, thus enabling greater trust in the entire system. The Chromatography Data System should be designed so that it provides not only greater speed and efficiency of the entire chromatographic process, but also that the entire process complies with the requirements of Good Manufacturing Practice. The implementation and validation of the Chromatography Data System does not mean that all requirements for Good Manufacturing Practice have been met. The Chromatography Data System should contain several basic characteristics to fully meet the regulatory requirements (Barrington-Light, 2017; FDA, 2016; McDowall, 2015a; McDowall, 2016a).

The Chromatography Data System should provide security, that is, controlled access to the software, with the possibility to create users and user groups, and implement adequate password control. This feature meets one of the basic requirements of Good Manufacturing Practice, attributing a particular activity to the person who performed the activity. Defining user groups with different privilege for access depending on the role they have in the system is of great importance because this prevents unauthorized personnel from accessing data or certain activities (21 CFR, Chapter 1, Part 221.25)

The Chromatography Data System must ensure that data is complete, that is, one analysis must contain all data related to it. This refers to data included in the final result, but also to all data, if any, where the obtained result is outside the specification limits or is an atypical result. Deleting data is unacceptable, and the easiest way to prove this request is through a technical control i.e. setting 
the system so that the end users do not have that privilege (21 CFR, Chapter 1, Part 221.194; Longden, 2017a)

Completeness of data implies provision of Audit Trail for each operation performed in the system. The Audit Trail is the most important form of metadata that contains critical information from which the entire process can be reconstructed sequentially. The Audit Trail is the chronological record of 'who, what, when and where' of data. The Chromatography Data System software must enable storage of metadata from every operation/activity instrument control, adjustments during the analysis, adjustments during data processing, preparation of the final report, etc. and connecting these activities to the original data in the moment of its creation. End users should not have the privilege to correct or delete the audit trail. The role of the administrator should be assigned to an independent service from the IT and telecommunications department that has no conflict of interest to perform critical adjustments in the system such as those related to audit trails, date and time settings as well as the privileges of other users (21 CFR, Chapter 1, Part 221.68; FDA, 2016; McDowall, 2015b; McDowall, 2016b; OMCL, 2018a; WHO, 2016).

The Chromatography Data System should have the possibility to connect not only to chromatographic systems from different manufacturers but also to other analytical instruments. The purpose of connecting different analytical instruments is to eliminate or reduce manual input of data as much as possible and replace this input with automatical transfer from the source where this data was generated in the first place through a validated process. Data entered manually are stated as critical data in clause 6 of EU GMP Annex 11 and require an additional check on accuracy and authenticity (Eudralex, 2011; McDowall, 2015b).

This paper presents the Data Integrity aspect of the installation and implementation of the Chromatography Data System in a control analytical laboratory and its meaning for the laboratory's workflow. Implementing such Chromatography Data System means having a transparent system which obtains overview of all activities connected to each generated data. The entire analytical process is automated, from the possibility to follow all activities related to each data in the system to automation of calculation and final reports from analytical results; as described in this paper with the Report Template for calculation of the specification parameter Related and Degradation Products as part of a Chromatography Data System.

While software and built-in technical control are the strongest element in providing data integrity, the human error factor is the most critical one. The origin of the errors is usually of a human nature, intentional or unintentional, after all people create, review and approve data. Their role in the entire process should be minimized to the extent that it does not affect the quality of the generated data, and the installation and implementation of such an automated system achieves this goal (Longden, 2017a; Longden, 2017b).

\section{Creating Report Template}

In order to maximize the value of implementing the Chromatography Data System, the transfer of data to other software should be reduced as much as possible. The entire workflow in the laboratory should be incorporated in the software, that is, end-users should not perform any activities outside the Chromatography Data System. This refers mostly to the calculation and issuing of the final results from the analysis.

Obtaining a report from data from one analysis is the final but not least significant step in the entire analytical process. One of the most important functions of any Chromatography Data System is to create a report of the processed data. Copying or exporting data to other software or applications is primarily time-consuming, but is also the cause of numerous errors. The Chromatography Data System should be designed to perform these activities alone by means of built-in or customized functions depending on the needs of the user. The possibility to create reports that will automatically calculate and display the required results without requiring additional software applications not only saves time and reduces the number of errors but also allows analysts to focus on the chromatographic aspect of the analysis instead of the calculations. This increases the productivity of the entire laboratory process. According to one statistical evaluation, the reduction in the time required to complete an analysis using such ready reports for routine analysis is approximately $80 \%$ (Dionex Technical Note 70; McDowall, 2016a).

The display of quantitative analytical results can be tabular or graphical. In general, tables are better used to display numerical information, in contrast to graphs used to visualize data while creating trends, making a comparison between results or showing some dependence. Tables and graphs should be clear and easily understandable, that is, the display of the data in them should allow for a better and easier understanding of the results without the additional need for text referencing. The title should be of informative character and outline the content. Numerical values should be represented by the same number of decimal units depending on the limits and acceptability criteria in the specification of the methodological procedure, as well as the acceptability criteria specified in the Standard Operating Procedure for validation of the report.

The content of a report depends on the type of results to be displayed as well as the user's requirements. The results of each testing must be presented accurately, clearly, unequivocally, objectively and in accordance with all the specific requirements in the methodological procedure and the end user. The requirements from the end user should be used to simplify the report as much as possible, but still contain the necessary information for an 
accurate interpretation of the results. The format should be chosen in such a way that it can be applied to each type of testing, as well as to reduce the possibility of misunderstanding and abuse. Reporting of data should be carried out through defined and verified processes and approved procedures, ensuring the consistency and integrity of the results that the report contains (GAMP, 2017; Huber, 2007; ISO/IEC 17025:2005).

Before beginning to design the report, it is necessary to define what the purpose of the report is and who is it intended for. A product is analyzed on several parameters that have different calculations, number of components being analyzed, and some even have defined acceptability criteria that need to be presented textually with the Pass/Fail criterion. This diversity in the requirements makes a big difference in the presentation of the results from various analysis, therefore, when implementing the Chromatography Data System, it is necessary to review all analyses that need to be included in the system and for which results should be reported. For each of these analyses it is necessary to create a report that would satisfy the requirements of the same. In the interest of the time used to create a single report, it is necessary to design them as generally as possible so that they can be used for multiple types of analyses. For example, when designing a report for the calculation of the parameter 'Related and Degradation Products', which we will discuss in more detail in this paper, the request for the evaluation of the results may be different:

- The evaluation of the result may be by excluding that result on the basis of the limit of quantification expressed in percent.

- The evaluation of the result may be by excluding the result on the basis of the disregard limit that may be expressed in percent or as a product of the specified disregard limit and the response of the calibration standard.

- The evaluation can also be without excluding any result.

Exactly because of this, the design phase of a report should not be skipped, that is, the stage of creating a report must not occur before all requests are carefully considered. The more time is spent on designing the report, the less time would be spent on correcting it in the future. After detailed consideration of all requirements, the creation of the report goes much faster and easier. This phase also includes creating a guide for daily use of the report as well as identifying all sections of the report that need to be validated. Upon completion of the creation phase, the report is subject to a testing phase, which should once again confirm that all requirements have been met. For this purpose, appropriate data is needed to simulate any possible requirement that the report meets. At this stage, it is recommended to check the content of cells, especially those containing formulas, the location of formulas, numbers and cell ranges. The check is carried out by two people, the one who created the report and another experienced person who knows the used functions and requirements (Blackwood, 2014; Esch et al., 2011; Huber, 2007; ISO/IEC 17025:2005).

The Thermo Scientific Chromeleon Chromatography Management System, characterized by powerful tools for calculation and presentation of data, was used to create the Report Template for calculation of the parameter 'Related and Degradation Products'. Calculations in the Chromeleon software can be performed through over 300 different built-in chromatographic functions, and it also supports user-defined formulas analogous to those used in Microsoft Excel software created for calculations that cannot be performed with the standard built-in functions (Dionex Technical Note 70).

Calculation of results in Chromeleon software is dynamical, which means that the report updates automatically as new data are obtained or method settings modified. The dynamic updating prevents inconsistencies between the entered settings and the final report of the analysis. Modifications in the report are only permitted prior to the application of electronic signatures, after which all data sources and settings that affect the results contained in that report are automatically locked. Locked data cannot be modified by anyone, and only the System Administrator can restrict who has the privilege to unlock the report. By generating an electronically signed report, the report content, the operator's identification and the signature stamped with date and time create a unique hash code which is stored along with the content of the report in an encoded binary document. If changes are made to the document, the electronic signature is displayed as invalid. These security measures prevent the possibility of signature or document falsification (Dionex Technical Note 54).

\section{Structure of Report Template}

The evaluation and interpretation of the large number of data that an analysis can contain is greatly facilitated if those data are organized in separate spreadsheets. This also facilitates the function of printing, i.e. exporting of results depending on the principle according to which the issuing of results in the laboratory works.

Below are the separate spreadsheets that we have included in the Report Template that is used to calculate the parameter 'Related and Degradation Products'.

\section{Sequence Overview Sheet}

In general, each report must contain sufficient basic information about the product and the parameter being analyzed, the status of the analysis, and of course, who prepared, reviewed and approved the analysis report. It is better to summarize this information in one spreadsheet from the report which can also include all injections in the sequence, chronologically aligned and thus give a clear overview of everything involved in the analysis. 
A brief review of this Sequence Overview Sheet gives insight into whether all the standards for meeting the system's suitability criteria are included, whether test injections are involved, whether there is a omitting of certain samples, and how many and which batches of the product are analyzed (Fig. 1). The analyzed product batch must be clearly linked to the reported result of the same (Eudralex, 2014; Huber, 2007; ISO/IEC 17025:2005; OMCL, 2014).

\section{Chromatogram Sheet}

Each separate injection included in the analysis with all relevant information related to it can be examined in the report through the Chromatogram Sheet which displays the chromatograms individually from sample to sample. The graph can be adjusted with data specific to the analysis, for example, to show the parameter relative retention time in the determination of 'Related and Degradation Products', and apart from basic data - the area and retention time, the table may include some parameters regarding the system suitability such as peak asymmetry or the number of theoretical plates (Dionex Technical Note 70).

\section{Calibration Sheet}

The data for the calibration curve and calibration standards are shown in the Calibration Sheet, which provides information on the calibration level of confidence, the type of calibration, how many and which points are included in the curve, and whether some of the calibration points are excluded in the evaluation (Fig. 2).

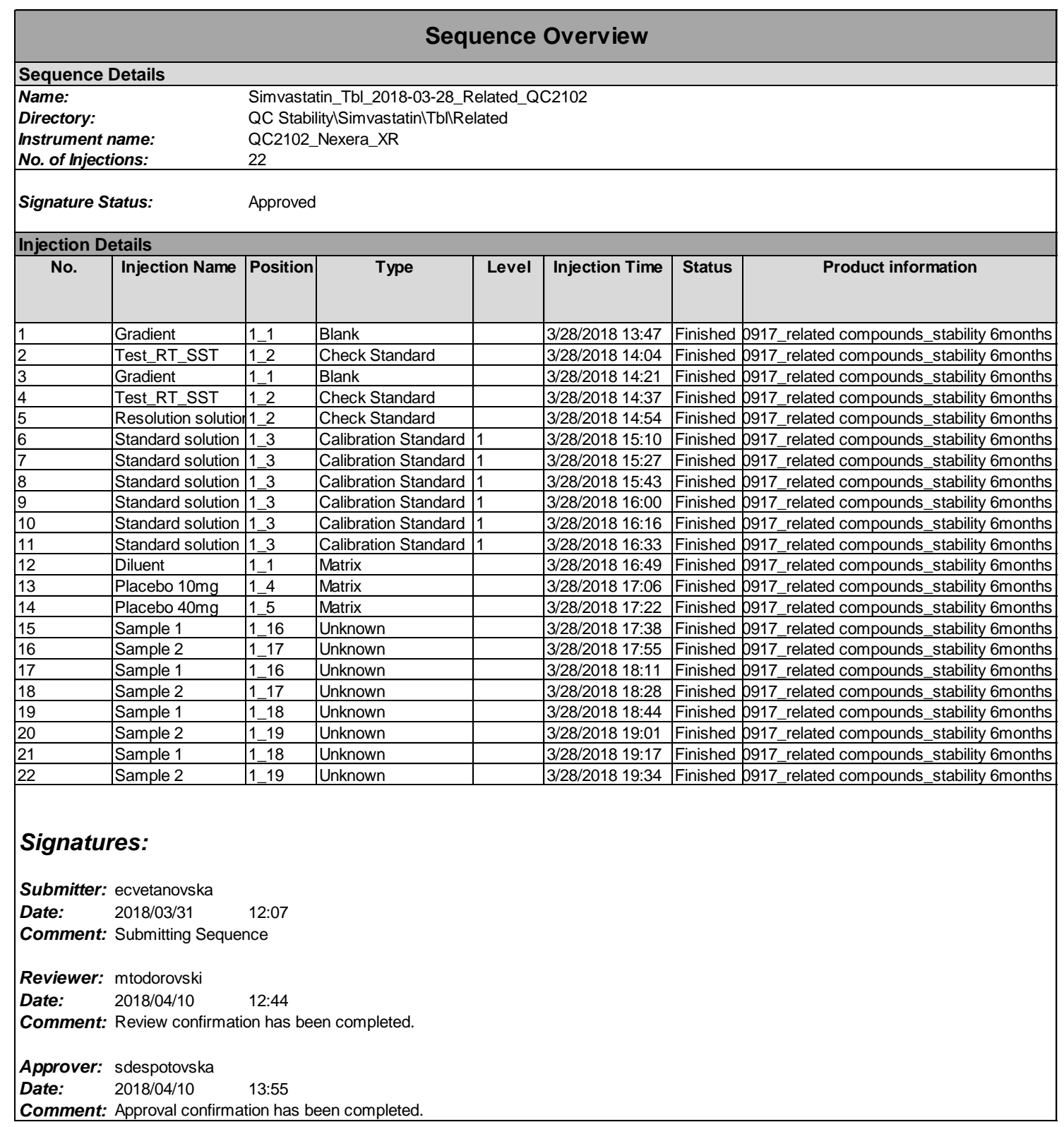

Fig. 1. Sequence Overview Sheet.

Макед. фарм. билт., 64 (1) 11 - 23 (2018) 


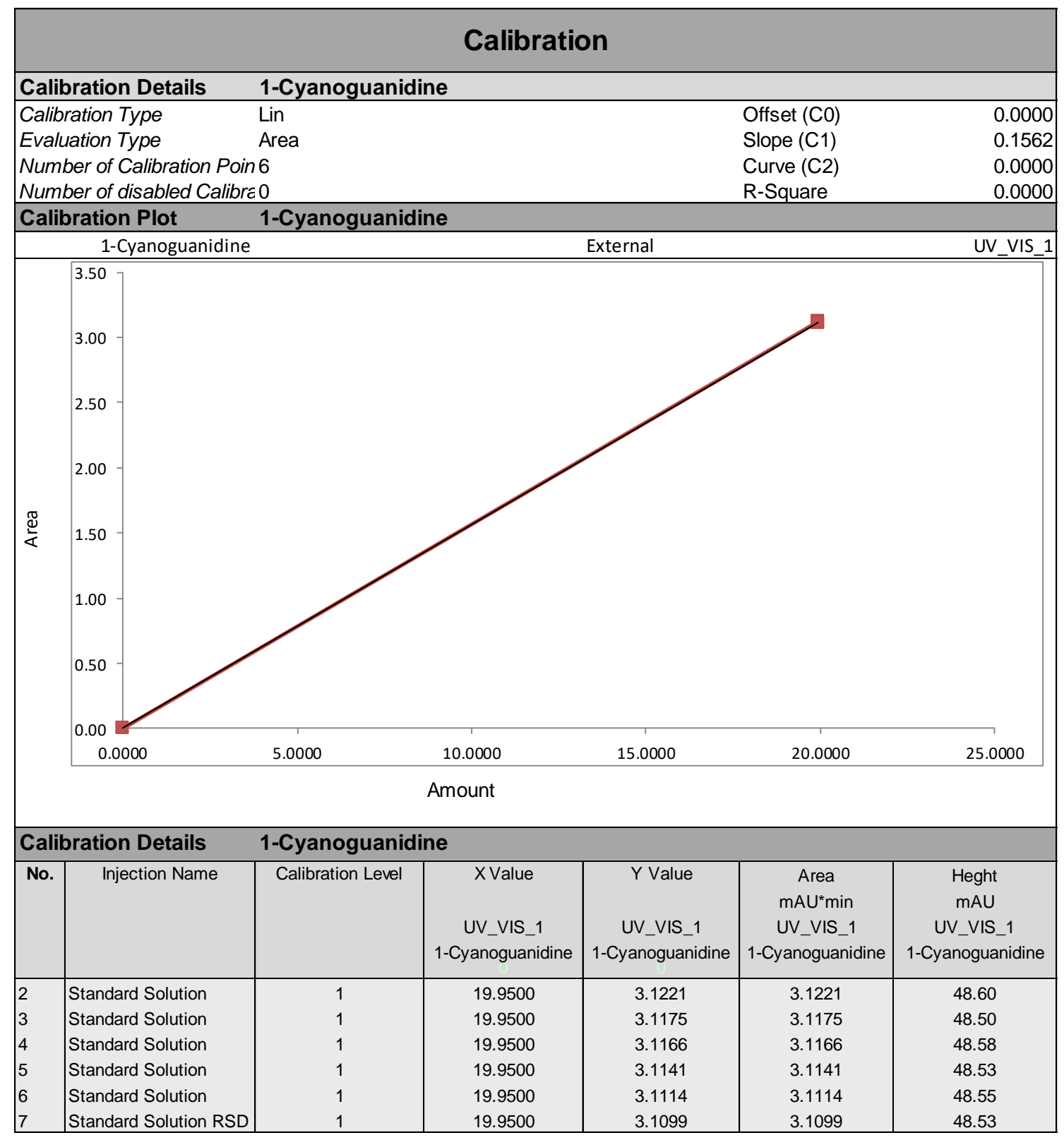

Fig. 2. Calibration Sheet.

The table, in addition to the basic information on the number and name of the injections and the area of the standards included in the calibration curve, can contain specific parameters such as $\mathrm{x}$ and $\mathrm{y}$ values for each calibration point in the curve. Along to tabular information, it is advisable to include a graphical representation of the calibration curve (Dionex Technical Note 70).

\section{Audit Trail Sheets}

The extensive number of data generated during an analysis in the Audit Trail hinder the process of review and may lead to inadvertent omission of important data. In order to facilitate this process, the Chromeleon software provides the opportunity to organize these data using two tables, Audit Trail Table and Data Audit Trail Table, which we have used in two separate spreadsheets.

The Injection Audit Trail Sheet gives an overview of all activities and messages for errors and/or warnings regarding the instrument. In the Audit Trail table, these activities and messages are presented for each injection separately.

Whereas the Data Audit Trail Sheet consists of detailed information for the analysis in whole. The Data Audit Trail table summarizes all changes at a sequence level, chromatogram, instrumental method, method for data processing and report, that is, all objects in the software where changes can be made. The changes are 
tracked and described by activity, date and time when they were made and by whom, as well as a comment that explains the reason for the change by the person who performed the activity.

We have additionally added one more Sequence Verification Sheet in the report to check the critical changes that may occur in an analysis in which simple excel formulas signal whether changes have been made during the analysis in the instrumental method, the volume and the position of an injection, and whether manual integration has been used.

\section{Summary SST Sheet}

System suitability tests are an integral part of chromatographic methods. They serve as a confirmation that the resolution and reproducibility of the chromatographic system are suitable for the analysis for which they are intended. The tests are based on the concept that instruments, electronic devices, analytical activities, and analyzed samples constitute an integral system that needs to be evaluated as a whole (USP 37, 2014). System suitability calculations are performed by monitoring the specific parameters of the standard solutions, in an ideal system the system suitability criteria must be met before the samples are applied. This request is enabled in the Chromeleon software by fully automating the entire process. The specific requirements of the analytical method, that is, the system suitability criteria are filled in the software which, after the detection of the appropriate component, performs automatic processing and calculates whether the specified criteria are met or not. Applying the subsequent injections in the sequence can be stopped if the criterion is not fulfilled or if that is the user's wish by a simple setting in the data processing method. This prevents the application of samples in a system that is not suitable for that analysis, as well as the waste of these samples and reagents (Dionex Technical Note 708).

Every request specified in the analytical procedure and entered in the data processing method is automatically calculated and included in the final report of the analysis in the Summary SST Sheet (Fig. 3). The Test Case Summary Table included in this spreadsheet can be customized according to the user's needs in relation to the information it contains. In our example we included the following parameters: number of tests, test name, number of injections included in the test, reference value, that is, the specified criterion, the evaluated result (numerical value), a textual result with a Pass/Fail criterion, a statistical condition and a name of the component through which the evaluation is carried out. Additionally, in the spreadsheet, we have included two tables showing the retention time and the area of the calibration standards. The built-in function in the second table also includes their average area, and an added simple excel formula gives the calculation of the relative standard deviation from the area in order to facilitate the process of checking the results.

\section{Summary Samples Sheet}

The final results from the analyzed samples are summarized in a Summary Samples Sheet. The quantitative results should be presented numerically, not using terms like 'suitable' or 'meets criteria', preferably in a table (ICH, Q3B(R2), 2006). When testing the parameter related and degradation products, a duplicate of two samples is injected (unless otherwise required), all detected impurities, specified and unspecified are

\begin{tabular}{|c|c|c|c|c|c|c|c|c|}
\hline \multicolumn{9}{|c|}{ Summary SST } \\
\hline \multicolumn{9}{|l|}{ Sequence Details } \\
\hline \multicolumn{2}{|l|}{$\begin{array}{l}\text { Name: } \\
\text { Directory: } \\
\text { Instrument name: } \\
\text { No. of Injections: }\end{array}$} & \multicolumn{7}{|c|}{$\begin{array}{l}\text { Carbocisteine_Cps_2018-05-16_Related_QC2009 } \\
\text { QC StabilitylCarbocisteinelCps } \backslash \text { Related } \\
\text { QC2009_ThermoUltimate } \\
37\end{array}$} \\
\hline \multicolumn{9}{|c|}{ System suitability criteria } \\
\hline Number & Name & No. & Name & Eval. Result & Ref. Value & Result & Statistics Count & Peak Name \\
\hline & $\begin{array}{ll}1 & \text { RSD of Peak Area } \\
2 & \text { Resolution (EP) } \\
\end{array}$ & $\begin{array}{l}12 \\
13 \\
14 \\
15 \\
16 \\
17 \\
11 \\
\end{array}$ & \begin{tabular}{|l|} 
Standard Solution \\
Standard Solution \\
Standard Solution \\
Standard Solution \\
Standard Solution \\
Standard Solution \\
Standard Solution \\
\end{tabular} & 1.4 & 5.0 & $\begin{array}{l}\text { Passed } \\
\text { Passed }\end{array}$ & \begin{tabular}{|l|}
6 \\
\\
1 \\
\end{tabular} & $\begin{array}{l}\text { Carbocisteine } \\
\text { Carbocisteine } \\
\text { Carbocisteine } \\
\text { Carbocisteine } \\
\text { Carbocisteine } \\
\text { Carbocisteine } \\
\text { Carbocisteine }\end{array}$ \\
\hline \multicolumn{9}{|c|}{ Calibration standards } \\
\hline Peak Name & $\begin{array}{l}\text { Ret.Time } \\
\text { Standard Solution }\end{array}$ & Standard Solution & 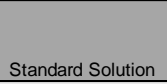 & 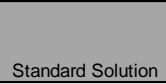 & Standard Solution & Standard Solution & & \\
\hline Carbocisteine & 30.80 & 30.79 & 30.65 & 30.62 & 30.66 & 30.67 & & \\
\hline Peak Name & $\begin{array}{l}\text { Area } \\
\text { Standard Solution }\end{array}$ & Standard Solution & Standard Solution & Standard Solution & Standard Solution & Standard Solution & Average & $\begin{array}{c}\text { Rel.Std.Dev. } \\
\%\end{array}$ \\
\hline Carbocisteine & 0.2933 & 0.3013 & 0.2931 & 0.2928 & 0.2889 & 0.2945 & 0.2940 & 1.4 \\
\hline
\end{tabular}

Fig. 3. Summary SST Sheet. 


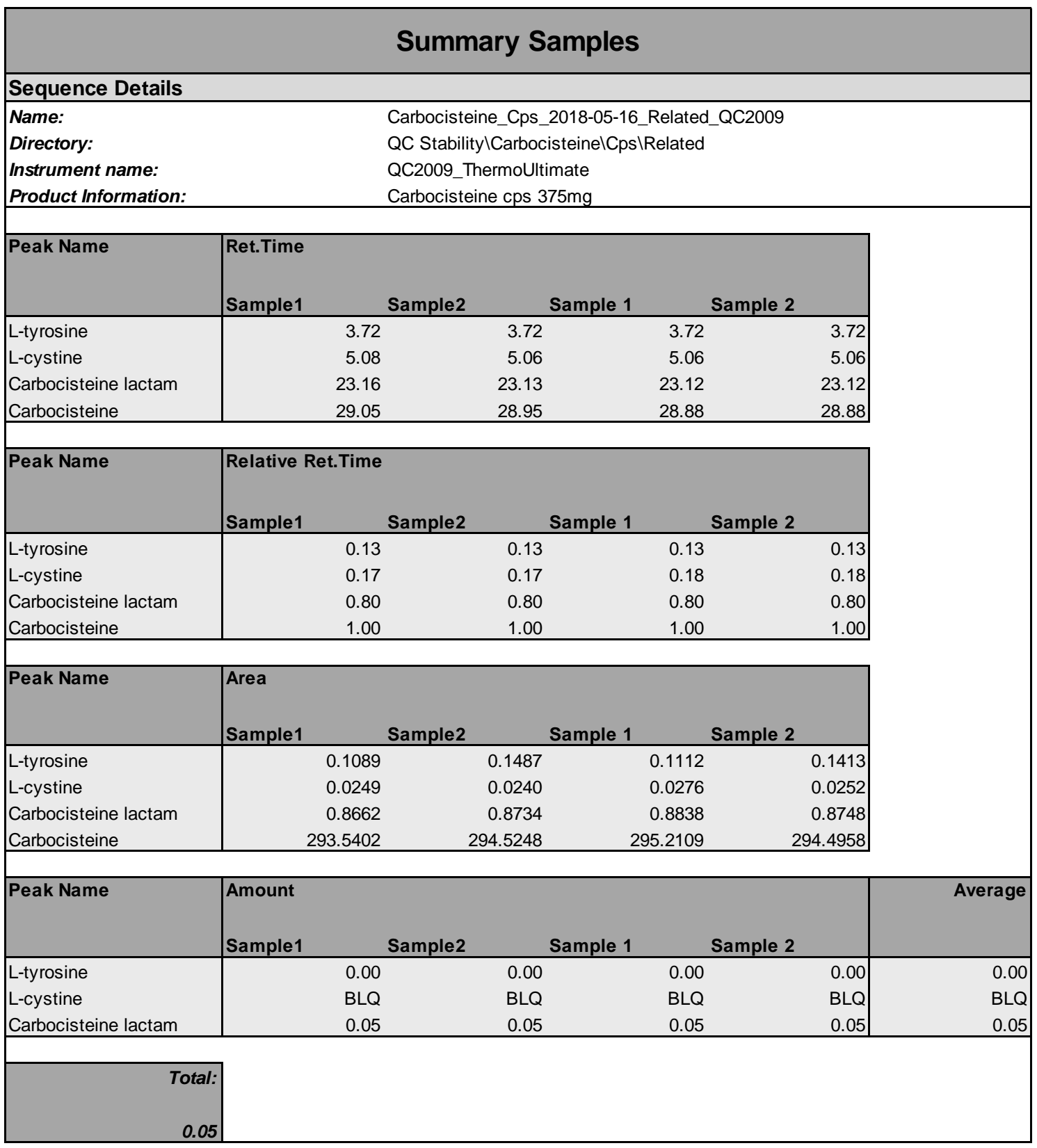

Fig. 4. Summary Samples Sheet.

identified and the average result of all four injections is calculated individually for each detected impurity (OMCL, 2014). The sum of all or certain impurities is calculated additionally, if such requirement exists. What makes this analysis specific is the unknown number of components to be reported, that is, it is not possible to predict in advance the number of components that will need to be determined and displayed in the report. Therefore, in order to display the results in this report, a Consolidate table is used where the increase in the number of components in turn increases the number of rows in the table, thus maintaining clarity of obtained results. The report contains more such tables, for each parameter that needs to be shown: retention time, area, relative retention time and final results and the amount of each detected impurity separately (Fig. 4).

The tables representing retention time, area and relative retention time of the components are assigned a logical condition in the formula for reporting specified components that are not detected with the abbreviation 'ND' (not detected). In this way, impurities that are not detected in the samples but are listed in the specification and in the data processing method are reported.

Calculation of the content of the detected impurities is carried out through custom formulas in which the area of the detected impurities is multiplied or divided, 
depending on the calculation formula with the appropriate custom variables created for this purpose. Custom variables are divided into two groups:

- Component custom variables that contain all the dilutions, weight, and other factors of the calculation formula that refer to standards.

- Injection custom variables that contain all the dilutions, weight and other factors of the calculation formula that refer to the samples.

Two such custom formulas are created, differing in the number of components that are taken in the calculation. The first formula, Peak Amount, calculates the content of each detected impurity individually (Fig. 5).

While the second formula, Peak Group Amount is used to calculate the content of components that are represented as a group and need to be quantified together (Fig. 6). When using the second formula it is necessary to make appropriate adjustments in the data processing method, that is, formation of a group for the components that are reported as one.

Distinction in the application between the two custom formulas is made by filling in the custom variable 'Formula' in the data processing method. To calculate the content of the components with the first formula, from the drop-down list of the custom variable 'Formula', the corresponding odd number is selected $-1,3,5$ or 7 , depending on the results evaluating requirement in the methodological procedure. While for calculation with the second formula the corresponding pair number is selected - 2, 4, 6 or 8 depending on the results evaluating requirement in the methodological procedure. The calculation of the content of the detected components is shown in the non-printable part of the sheet. From there it is referenced in the table for reporting the final result depending on the evaluation.

Evaluation of the results in the table for reporting the content of each component is individually carried out depending on the requirements in the methodological procedure. The report is adapted to evaluate the results without rejecting any result, the evaluation can be performed by excluding the results by comparing it with the specified limit of quantification, by comparing with the disregard limit expressed in percent or by comparing with the disregard limit expressed as product of the specified disregard limit and the response of the calibration standards. Settings depending on the requirements in the methodological procedure are performed in the data processing method by appropriate filling in the custom variables created for this purpose.

The report is adapted for eight types of calculations depending on which option is selected from the dropdown list of the custom variable 'Formula' as described below:

1. By selecting number 1 , the content of each component is calculated separately using the custom Peak Amount formula without rejecting any result.
2. By selecting number 2, the content of the components presented as a group is calculated using the custom Peak Group Amount formula without rejecting any result.

3. By selecting number 3, the content of each component is calculated separately using the custom Peak Amount formula and the result is evaluated based on the specified limit of quantification. In case the content of any impurity is lower than the specified limit of quantification, the result is reported as ' $B L Q$ ' (below limit of quantification) using the following custom formula:

if(cf.peak_amount>component.customVar("BLQ"),cf. peak_amount,"BLQ")

4. By selecting number 4, the content of the components presented as a group is calculated using the custom Peak Group Amount formula and the result is evaluated based on the specified limit of quantification. In case the content of the impurities presented as group is lower than the specified limit of quantification, the result is reported as ' $B L Q$ ' (below limit of quantification) using the following custom formula:

if(cf.group_amount>component.customVar("BLQ"),c f.group_amount, "BLQ")

5. By selecting number 5, the content of each component is calculated separately using the custom Peak Amount formula and the result based on the disregard limit obtained as the product of the specified disregard limit and the response of the calibration standards is evaluated. In this case, the evaluation is done by comparing the area of the impurity and the resulting product of the specified disregard limit and the response of the calibration standards. If the area of any impurity is lower than this product, the result is reported as ' $B D L$ ' (below disregard limit) using the following custom formula:

if(peak.area >(chm.peak("bycondition", "component.c ustomVar $\backslash$ "Main_component $\left.\mathrm{N}^{\prime \prime}\right)=\backslash^{\prime}$ yes $\backslash$ '"').calPointF $X(1) *$ component.customVar("BDL")),cf.peak_amoun $\left.t, " B D L^{\prime \prime}\right)$

6. By selecting number 6 , the content of the components presented as a group using the custom Peak Group Amount formula is calculated and the result based on the disregard limit obtained as the product of the specified disregard limit and the response of the calibration standards is evaluated. In this case, the evaluation is done by comparing the sum of the areas of the components represented in a group and the product of the specified disregard limit and the response of the calibration standards. If the 
sum of the areas of the components in the group is lower than this product, the result is reported as ' $B D L$ ' (below disregard limit) using the following custom formula:

if(peak.groupArea >(chm.peak("bycondition", "comp onent.customVar $(\backslash$ "Main_component $\backslash ")=\backslash " y e s \backslash "$ ").ca lPointFX(1)*component.customVar("BDL")),cf.grou p_amount,"BDL")

7. By selecting number 7, the content of each component is calculated separately using the Peak Amount formula and the result is evaluated based on the specified disregard limit expressed in percent. In case the content of any impurity is lower than the specified disregard limit, the result is reported as ' $B D L$ ' (below disregard limit) using the following custom formula:

\section{if(cf.peak_amount>component.customVar("BDL"),cf .peak_amount, "BDL")}

8. By selecting number 8 , the content of the components represented as a group using the custom Peak Group Amount formula is calculated and the result is evaluated based on the specified disregard limit expressed in percent. In case the content of the impurities presented as group is lower than the specified disregard limit, the result is reported as ' $B D L$ ' (below disregard limit) using the following custom formula:

\section{if(cf.group_amount>component.customVar("BDL"), cf.group_amount,"BDL").}

Depending on the requirements, the custom variables 'BDL' and 'BLQ' are filled in accordingly. When using formulas 1 and 2 , these variables are left blank, if the formulas 3 and 4 are used, the variable 'BLQ' is filled in with the appropriate value for the quantification limit, if the formulas 5, 6, 7 and 8 are used, the variable 'BDL' is filled in with the appropriate value for the disregard limit.

\section{Validation of Report Template}

With all these settings in the data processing method and in the report itself, the calculation of the results is consistent and accurate regardless of the number of the components to be determined and the number of applied samples. Certainly, for confirmation of this, the report should be subjected to proper validation before being put into use for formal analysis. The purpose of the validation process is to demonstrate that the created report is valid for its purpose. This process should show that the result obtained from the processed data through calculations, rounding, formatting and regrouping is accurate and reproducible. The results obtained from Chromeleon's built-in chromatographic functions do not require further validation because these functions have been tested during the software development by the manufacturer and during the installation of the software as part of Operational Qualification. All calculations performed with formulas defined by the user are subject to validation (Dionex Technical Note 70). Verification of the calculations is done by comparing the obtained results with completely independent software and the results obtained in the report which is validated, using the same data (OMCL, 2018b). The comparison is documented with screenshots identified with the name of the report, the user ID, the spreadsheet name, and the date and time when the validation is performed (Phan, 2003). The screenshots besides the general information about the use and content of the report are an integral part of the validation documentation. Documentation of the entire validation process is an equally important phase of the validation process (Phan, 2003). Minimum deviations may occur due to the different rounding of the decimal places, which is why it is necessary for acceptance criteria to be defined. Acceptance criteria are selected appropriately so that the accuracy of the calculation does not affect the accuracy of the chromatographic method (Esch et al., 2011). The deviations that arise during the validation process should be stated and explained in the validation documentation (FDA, 2013; Phan, 2003).

End users should not be able to modify validated reports. They are only allowed to perform settings in the

peak.Amount*component.customVar("Standard_Pipette_1")*component.customVar("Standard_Pipette_2")*component .customVar("Standard_Pipette_3")*component.customVar("Standard_Pipette_4")/component.customVar("Standard_Di lution_1")/component.customVar("Standard_Dilution_2")/component.customVar("Standard_Dilution_3")/component.c ustomVar("Standard_Dilution_4")/component.customVar("Standard_Dilution_5")*component.customVar("Multiplier_ 1")*component.customVar("Multiplier_2")/component.customVar("Divider_1")/component.customVar("Divider_2")*i njection.customVar("Sample_Dilution_1")*injection.customVar("Sample_Dilution_2")*injection.customVar("Sample_ Dilution_3")*injection.customVar("Sample_Dilution_4")*injection.customVar("Sample_Dilution_5")/injection.custom Var("Sample_Pipette_1")/injection.customVar("Sample_Pipette_2")/injection.customVar("Sample_Pipette_3")/injectio n.customVar("Sample_Pipette_4")*injection.customVar("Multiplier_3")*injection.customVar("Multiplier_4")*injectio n.customVar("Multiplier_5")/injection.customVar("Divider_3")/injection.customVar("Divider_4")/injection.customVar ("Divider_5")

Fig. 5. Custom Formula, Peak Amount. 
peak.groupAmount*component.customVar("Standard_Pipette_1")*component.customVar("Standard_Pipette_2")*com ponent.customVar("Standard_Pipette_3")*component.customVar("Standard_Pipette_4")/component.customVar("Stand ard_Dilution_1")/component.customVar("Standard_Dilution_2")/component.customVar("Standard_Dilution_3")/comp onent.customVar("Standard_Dilution_4")/component.customVar("Standard_Dilution_5")*component.customVar("Mul tiplier_1")*component.customVar("Multiplier_2")/component.customVar("Divider_1")/component.customVar("Divide r_2")*injection.customVar("Sample_Dilution_1")*injection.customVar("Sample_Dilution_2")*injection.customVar("S ample_Dilution_3")*injection.customVar("Sample_Dilution_4")*injection.customVar("Sample_Dilution_5")/injection. customVar("Sample_Pipette_1")/injection.customVar("Sample_Pipette_2")/injection.customVar("Sample_Pipette_3")/i njection.customVar("Sample_Pipette_4")*injection.customVar("Multiplier_3")*injection.customVar("Multiplier_4")*i njection.customVar("Multiplier_5")/injection.customVar("Divider_3")/injection.customVar("Divider_4")/injection.cust omVar("Divider_5")

Fig. 6. Custom Formula, Peak Group Amount.

tables depending on which data should be displayed, and filling in certain fields with data that are intended to be entered during the analysis or after its completion. In order to fulfill this requirement and to protect the reports from unintentional or intentional changes it is necessary to lock all the fields in the report used for calculation (FDA, 2013; GAMP, 2017; OMCL, 2018b).

Upon the completion of validation, the report is reviewed and approved by an authorized person who knows the used functions and requirements, after which it can be used for formal analysis. The validated reports are stored in a locked folder where the end users can use them only by copying them into a suitable working sequence without making any changes to them (GAMP, 2017).

\section{Conclusion}

This paper describes the process of obtaining accurate and reliable results for the specification parameter Related and degradation products through creating Report Template as part of Chromatography Data System. As it has been shown the use of this validated Report Template facilitates evaluation of results for this type of analysis and makes them readily available for review or inspection. Automating the process of calculating and reporting the results of chromatographic analyses in the Chromatography Data System has a huge benefit for a control analytical laboratory. Not only time and resources are saved in this way, but the end users are also released from the pressure of error in issuing results and can dedicate themselves to the scientific aspect of their work. Thus, the entire workflow in the laboratory is promoted.

\section{Acknowledgement}

The author would like to thank Alkaloid AD-Skopje, Pharmaceutical, Chemical and Cosmetics Company for support, comments and suggestions made during the process of writing this paper.

\section{References}

Barrington-Light, D., 2017. Informatics \& Chromatography Software, Data Integrity Challenges in Pharmaceutical Manufacturing: Meeting Tomorrow's Guidelines Today, Bioscience Technology.

Blackwood, N., 2014. Advanced Excel reporting for Management Accountants, Wiley Corporate F\&A, Kindle Edition.

Churchward, D., 2015. Good Manufacturing Practice (GMP) data integrity: a new look at an old topic, part 1, MHRA Inspectorate Blog. Available at:

https://mhrainspectorate.blog.gov.uk/2015/06/25/goodmanufacturing-practice-gmp-data-integrity-a-new-look-atan-old-topic-part-1/.

Churchward, D., 2015. Good Manufacturing Practice (GMP) data integrity: a new look at an old topic, part 2, MHRA Inspectorate Blog. Available at:

https://mhrainspectorate.blog.gov.uk/2015/07/14/goodmanufacturing-practice-gmp-data-integrity-a-new-look-atan-old-topic-part-2/.

21 Code of Federal Regulations (CFR) Chapter I, Part 221.25. Current Good Manufacturing Practice for Finished Pharmaceutical Products, Personnel qualifications.

21 Code of Federal Regulations (CFR) Chapter I, Part 221.68. Current Good Manufacturing Practice for Finished Pharmaceutical Products, Automatic, mechanical, and electronic equipment.

21 Code of Federal Regulations (CFR) Chapter I, Part 221.180. Current Good Manufacturing Practice for Finished Pharmaceutical Products, Records and Reports, General requirements.

21 Code of Federal Regulations (CFR) Chapter I, Part 221.194. Current Good Manufacturing Practice for Finished Pharmaceutical Products, Laboratory records.

Dionex Technical Note 54 - Using Chromeleon Chromatography Management Software to Comply with 21 CFR Part 11. Available at:

http://tools.thermofisher.com/content/sfs/brochures/TN-54Chromeleon-21-CFR-Part-11-LPN1302-EN.pdf.

Dionex Technical Note 70 - Data Reporting in Chromeleon. Available at: http://dionex.su/en-us/documents/technicalnotes/automation/lp-72154.html. 
Dionex Chromeleon 7 Chromatography Data System Software Technical Note 708.

Esch, P.M., Moor, C., Schmid, B., Albertini, S., Hassler, S., Donzé, G., Saxer, H.P., 2011. Good Laboratory Practice (GLP) - Guidelines for the Development and Validation of Spreadsheets. The Quality Assurance Journal 13(34), 41-56. Available at: https://doi.org/10.1002/qaj.466.

European Commission Health and Consumers DirectorateGeneral, Eudralex, June 2011. The Rules Governing Medicinal Products in the European Union, Volume 4: Good Manufacturing Practice, Medicinal Products for Human and Veterinary Use, Annex 11, Computerised Systems. Available at: https://ec.europa.eu/health/sites/health/files/files/eudralex/ vol-4/annex11_01-2011_en.pdf.

European Commission Health and Consumers DirectorateGeneral, Eudralex, October 2014. The Rules Governing Medicinal Products in the European Union, Volume 4: Good Manufacturing Practice, Medicinal Products for Human and Veterinary Use; Chapter 6 Quality Control. Available at:

https://ec.europa.eu/health/sites/health/files/files/eudralex/ vol-4/2014-11_vol4_chapter_6.pdf.

FDA - US Food and Drug Administration, 2013. Volume III, Section 4.5, Development and validation of Spreadsheets for calculation of Data. Available at: https://www.fda.gov/media/73535/download.

FDA - US Food and Drug Administration, April 2016. Data Integrity and Compliance With cGMP, Guidance for Industry. Available at: https://www.fda.gov/files/drugs/published/Data-Integrityand-Compliance-With-Current-Good-ManufacturingPractice-Guidance-for-Industry.pdf.

GAMP Good Practice Guide, March 2017. Records and Data Integrity, International Society for Pharmaceutical Engineering. Available at: https://ispe.org/publications/guidance-documents/gamprecords-pharmaceutical-data-integrity.

Huber, L., 2007. Validation and Qualification in Analytical Laboratories, Second Edition, Informa Healthcare USA, Inc.

ICH Harmonised Tripartite Guideline, June 2006. Impurities in New Drug Products, Q3B(R2). Available at: https://www.ema.europa.eu/en/documents/scientificguideline/ich-q-3-b-r2-impurities-new-drug-products-step5_en.pdf.

ISO/IEC 17025:2005. General requirements for the competence of testing and calibration laboratories. Available at: https://www.iso.org/standard/39883.html.

Longden, H., 2017. Understanding Data Integrity: Your Guide to Ensuring Confidence, Reliability and Trust in your People, Processes and Data; Why is Electronic CDS Data a Mayor Data Integrity Concern for Regulators?

Longden, H., 2017. Understanding Data Integrity: Your Guide to Ensuring Confidence, Reliability and Trust in your People, Processes and Data - New Challenges in Electronic Data Collection and Oversight.
McDowall, R., Burgess, C., 2015. The Ideal Chromatography Data System for Regulated Laboratory, Part I: The Compliant Analytical Process. LCGC North America 33(8), 554-557. Available at:

http://www.chromatographyonline.com/ideal-

chromatography-data-system-regulated-laboratory-part-icompliant-analytical-process.

McDowall, R., Burgess, C., 2015. The Ideal Chromatography Data System for Regulated Laboratory, Part II: System Architecture Requirements, LCGC North America 33(10), $782-785$.

McDowall, R., 2016. Validation of Chromatography Data Systems: Ensuring Data Integrity, Meeting Business and Regulatory Requirements, second ed. Royal Society of Chemistry.

McDowall, R., Burgess, C., 2016. The Ideal Chromatography Data System for Regulated Laboratory, Part IV: Assuring Regulatory Compliance. LCGC North America, 34(2), 144-149. Available at:

http://www.chromatographyonline.com/ideal-

chromatography-data-system-regulated-laboratory-part-ivassuring-regulatory-compliance.

MHRA, March 2015. GMP Data Integrity Definitions and Guidance for Industry. Available at: http://academy.gmpcompliance.org/guidemgr/files/Data_integrity_definitions _and_guidance_v2.pdf.

MHRA, March 2018. GXP Data Integrity Guidance and Definitions. Available at:

https://assets.publishing.service.gov.uk/government/uploa ds/system/uploads/attachment_data/file/687246/MHRA_G xP_data_integrity_guide_March_edited_Final.pdf.

OMCL Guideline, October 2014. Evaluation and Reporting of Results. PA/PH/OMCL (13) 113 2R. Available at: https://www.edqm.eu/sites/default/files/medias/fichiers/O MCL/Quality_Management_Documents/omcl_evaluation _and_reporting_of_results_-_core_document.pdf.

OMCL Guideline, August 2018. Validation of Computerized Systems. PA/PH/OMCL (08) 69 R7.Available at: https://www.edqm.eu/sites/default/files/guidelines-omclcomputerised_systems-core_document-march2018.pdf.

OMCL Guideline, August 2018. Validation of Computerized Systems, Annex 1 - Validation of Excel Spreadsheet. PA/PH/OMCL (08) 87 R6. Available at: https://www.edqm.eu/sites/default/files/guidelines-omclcomputerised-systems-annex1-march2018.pdf.

Phan, T.T., 2003. Pharmaceutical Technology, Technical Considerations for the Validation of Electronic Spreadsheets for Complying with 21 CFR Part 11. Available at:

http://files.alfresco.mjh.group/alfresco_images/pharma//20 14/08/22/7432aebb-9f08-40f2-aa06-039b05f0fd6a/article42756.pdf.

United States Pharmacopeia (USP 37, NF 32), May 2014. Chromatography General Chapter, 621.

World Health Organization, 2016. Guidance on Good Data and Record Management Practices, Annex 5. Available at: https://apps.who.int/medicinedocs/en/m/abstract/Js22402e $\mathrm{n} /$. 
Резиме

\title{
Прикажување на резултати од параметарот сродни и деградациони продукти од аспект на зачувување на интегритетот на податоците во софтвер за хроматографско управување
}

\author{
Милена Добрковиќ Шотаровска ${ }^{1 *}$, Христина Бабуновска ${ }^{1}$, Анета Димитровска ${ }^{2}$ \\ ${ }^{1}$ Алкалоид АД, Фармацевтска, Хемиска и Козметичка Индустрија, \\ Александар Македонски 12, 1000 Скопје, Република Македонија \\ ${ }^{2}$ Универзитет „Св. Кирил и Методиј”, Фармацевтски факултет, Мајка Тереза 47, \\ 1000 Скопје, Република Македонија
}

Клучни зборови: интегритет на податоци, софтвер за хроматографски податоци, прикажување на резултати, сродни и деградациони продукти

Работниот тек во една контролна аналитичка лабораторија треба да биде сообразен со начелата на Добра производствена пракса и се што ќе се генерира како податок во неа треба да ги прати принципите за интегритет на податоци. Најлесен начин да се постигне оваа цел е целиот аналитички процес што е можно повеќе да се автоматизира.

Добивање на краен веродостоен резултат од едно аналитичко испитување кое е дел од формална анализа е еден сегмент од процесот на обезбедување на Добра производствена пракса за една аналитичка лабораторија. Во овој труд ги опишуваме сите чекори со кои една контролна аналитичка лабораторија може да го формализира и автоматизира целиот процес на добивање и издавање на аналитички резултати преку креирање на шаблон за прикажување на резултати од параметарот сродни и деградациони продукти како дел од софтвер за управување со хроматографски податоци. Процесот е опишан во неколку чекори од дизајнирање и структурно определување на шаблонот како истиот би одговорил најдобро на барањата на крајниот корисник, преку негово тестирање како би се утврдиле евентуалните пропусти во фазата на креирање, до крајната фаза негова валидација со што уште еднаш се потврдува интегритетот на неговата содржина и истиот може да се користи за формални анализи.

Со употреба на вакви валидирани шаблони за пресметка и прикажување на резултатите од аналитичкото испитување се исклучува факторот човечка грешка и се зголемува довербата во издадените резултати како и во целиот работен тек на лабораторијата. Нивната употреба ја олеснува сообразноста со регулаторните барања и го сведува на минимум мануелното внесување на податоците со што се исполнува едно од најкритичните регулаторни барања за Добра производствена пракса. 
